\title{
An Investigation of the Impact of Facebook and Instagram on Consumer Buying Behaviour: The Case of Retail Fashion Consumers in Rhodes, Greece
}

\author{
Dionisia Tzavara ${ }^{1 \uparrow}$, Phaedra Clarke ${ }^{2}$, Fotios Misopoulos ${ }^{3}$ \\ Laureate Online Education, C River Building, Haarlerbergweg 23, Amsterdam/Netherlands and University of Liverpool, Chatham Street, Liverpool/UK \\ 'Hunemoller Belgium, Frankrijlei 65, Antwerpen/Belgium \\ University of Liverpool, Chatham Street, Liverpool./UK
}

\begin{tabular}{l}
\hline ARTICLE INFO \\
\hline Article History \\
Received 06/11/2019; \\
Accepted 15/12/2019
\end{tabular}

JEL Classifications M30, M31, M39

\section{ABSTRACT}

\section{Purpose}

The aim of this paper is to explore the impact of Facebook and Instagram on consumer buying behaviour in the retail fashion market in Rhodes, Greece. We look at the extent to which the two social media influence Rhodian consumer preferences toward certain stores and at whether Rhodians use these social media for fashion information and inspiration.

Design/methodology/approach:

The study is conducted online, using quantitative methodology and close-ended survey questionnaires to obtain data.

Finding:

We find that Facebook and Instagram influence Rhodian consumer behaviour. Rhodians believe that the two social media are a good way to follow fashion trends and that fashion is more accessible because of Facebook and Instagram compared to five years ago. The Rhodians seem to be getting fashion inspiration from Facebook and/or Instagram but more in a passive manner than through active engagement with fashion on the two social media.

Research limitations/implications:

Our findings demonstrate that Facebook and Instagram are very powerful in bringing fashion closer to consumers and they underline the role that these social media can plan in the marketing mix. Our findings can be used by fashion retailers to inform their social media engagement strategies and decisions. Our research can be extended to investigate the impact of different social media constructs on consumer behaviour and to look at what type of social media content may be more impactful in shaping shopping behaviour.

Originality/value:

Research on the subject of how social media impacts the behaviour of fashion consumers in Greece is limited and literature on the retail fashion market is noticeably scarce. Studies

Keywords: Consumer Buying Behaviour, Social Media Marketing, Retail Fashion, Greece published on the topic of social media influencing consumer decisions with a focus on the Greek market are almost exclusively confined to the tourism sector. Our findings can be used by fashion retailers to inform their social media engagement strategies and decisions.

\section{Introduction}

Social media as changed the way companies communicate with consumers. Not only has social media created new marketing opportunities for companies (Brunh, Schoenmueller \& Schafer, 2012; Goodrich \& Mooij, 2013; Hajli, 2014; Felix, Rauschnabel \& Hinsch, 2017) but also companies can us social media to engage in a dialog with consumers and to promote their brand and market their products/services (Lim, et.al., 2006; Hajli, 2014; Godey et. al., 2016; Lin, Li \& Wang, 2017). At the same time, social media is a source of rich information for consumers about brands and products/services (Brunh, Schoenmueller \& Schafer, 2012; Hudson \& Hudson, 2013). Social media has also created opportunities for consumers to share views and opinions about product/services with other consumers (Kim \& Park,

${ }^{\dagger}$ Corresponding Author: Dionisia Tzavara

e-mail: dionisia.tzavara@online.liverpool.ac.uk 
2013; Hudson \& Hudson, 2013; Lin, Li \& Wang, 2017) and to create content about brands and products (Patino, Pitta \& Quinones, 2012; Brunh, Schoenmueller \& Schafer, 2012; Goh, Heng \& Lin, 2013; Hajli, 2014; Chen, Lu \& Wang, 2017). Consumers share their reviews and recommendations about products/services through social media and they discuss their experiences with products/services with their online social network (Hajli, 2014; Lin, Li \& Wang, 2017; Chen, Lu \& Wang, 2017). There is no doubt that brand related content and brand presence on social media impact consumer decisions and behaviour (Kim \& Ko, 2012; Goh \& Heng, 2013; Hudson \& Hudson, 2013; Rathore, Ilavarasan \& Dwivedi 2016; Gautam \& Sharma, 2017; Perakakis et. al., 2018; Nash, 2019).

The fashion industry is quickly embracing social media, with brands increasingly turning to social media to connect with their customers (Park, Ciampaglia \& Ferrara, 2016; Gautam \& Sharma, 2017; Nash, 2019). Fashion brands are developing their own specialised webpages which contain information about the brand and offer space for consumers to connect with the brand and interact with other consumers ( $\mathrm{Ng}, 2014)$. Consequently, it is important for fashion brands to understand how social media is impacting consumer decisions and behaviour.

As a result of the financial crisis, the market in Greece in general has suffered a significant downturn and continues to be under significant pressure. However, despite the downturn, the apparel market seems to slowly pick up in the past 4-5 years and to show prospects for growth in the coming years as well (The Statistics Portal, 2018a), with large multinational clothing chains gaining shares (Euromonitor International, 2019). According to The Statistics Portal (2018b), the retail sector that is hosting the highest number of retail chains in the country is fashion and clothing. Also, internet usage in the country is increasing (Hellenic Statistical Authority, 2018; The Statistics Portal, 2019), and connecting buyers and sellers through social media in the country is growing (ELTRUN, 2016). Users feel more mature to use social media to connect with brands, and trust on the information that is available on social media is increasing. Social media is developing into an important tool in creating a "conversation" between companies and consumers in the country (ELTRUN, 2016).

The study will take an in depth look at how exposure to Facebook and Instagram has changed the way Rhodians shop for fashion and at how these two social media have impacted the Rhodian consumers' behaviour toward fashion. Our study will look at whether having an Instagram or Facebook account drives Rhodian consumers to shop at specific stores and if social media are a source of fashion information for the Rhodians. We choose to focus on the island of Rhodes in Greece, because in the past 10 years the island has seen the arrival of several chain fashion retailers. Not just an attractive market for large retailers, Rhodes has also seen growth in local boutiques. We choose to focus on Instagram and Facebook as these two are largely the two most popular social media in Greece (Hutt, 2017; Vincos, 2019), with Facebook being the most popular social media with Instagram being second. Also, Instagram seems to be a very popular outlet for brands and fashion related activity (Cartner-Morley, 2015a \& b).

\section{Literature Review}

In today's fast paced world, social media offer an avenue for "conversation" between buyers and sellers that was previously unimaginable (Hajli, 2014; Rathore \& Ilavarasan, 2016). Social media has created opportunities to move away from one sided communication from companies to consumers, to a two-way conversation and to consumer engagement (Rathore \& Ilavarasan, 2016; Schivinski \& Dabrowski, 2016). Social media has advanced from a medium where people could communicate easily with friends and family, to a platform where they can also easily learn about retail trends and new products and where they can share views and opinions about products and services. The use of social media to market products and services now provides a new way for consumers to shop, but also new avenues for them to learn more about what they purchase before actually following through (Shankar et al. 2011; Erkan \& Evans, 2016; Chen, Lu \& Wang, 2017).

Social media can be used to gather information about consumer behaviour and to conduct analysis, leading to a greater understanding of how the toll can be used to better market products and services (Paquette, 2013; Rathore \& Ilavasaran, 2016; Felix, Rauschnabel \& Hinsch, 2017). The inclusion of social media in the promotional mix radically changes the reach of promotion, and thus should never be overlooked as an important tool in the promotion of goods and services (Paquette, 2013; Felix, Rauschnabel \& Hinsch, 2017). For companies, the use of social media as a marketing tool is ever more lucrative, with 'Fortune 500' companies using the tool increasingly over the past few years (Hatzithomas, Fotiadis \& Courdounaris 2016). Through social media, companies gain attention for their product/service and brands can build stronger relationships with consumers, who can share opinions on products and services (Felix, Rauschnabel \& Hinsch, 2017). With the focus of marketing shifting from product-centric to customercentric, understanding the impact of social media on consumer behaviour is paramount (Geissinger \& Laurel, 2016; Felix, Rauschnabel \& Hinsch, 2017). Social media offer a dynamic environment in which consumers can communicate their experiences to others and create high interconnectedness with other users of the same products/services, adding personal relevance to consumer experience (Shadkam \& O’Hara, 2013; Chen, Lu \& Wang, 2017).

Fashion is especially well suited to "collaborate" with social media, as fashion "is known to spread through network effects” (Wonly \& Mueller, 2013, 563). According to Wolney and Mueller (2013), fashion is a powerful social symbol, which can help create personal and group identities. The ability to express one's self through fashion could be considered to have a direct relationship with social media as now people can express themselves through Facebook and/or Instagram. Social media represent a personal platform for the expression of ideas, and this resonates with fashion conscious users as it gives them another outlet for creative expression (Geissinger \& Laurel, 2016). A lot of discussion about fashion is happening in online communities as fashion entails a social element, and users are seeking opinions about and evaluation of their style choices from their network (Wolney \& Mueller, 2013). Also, the fashion 
industry is very dynamic and innovative, with trends changing constantly (Mohr, 2013; Kontu \& Vecchi, 2014; Perry \& Kyriakaki, 2014). Ahmad, Salman \& Ashiq (2015) argue that social media is uniquely suited to the promotion of fashion, as both of them grow and evolve at a fast pace, following consumer opinions and desires/needs. Thus, the relationship is clear: social media can keep up with fashion's fast pace.

Although the fashion industry was initially reluctant to develop a presence on social media, it is recently embracing social media at a fast pace (Morh, 2013; Kontu \& Vecchi, 2014). Fashion retailers are using social media to connect and to engage in conversation with consumers, to strengthen their brand and promote their products/services, and to collect information about consumer behaviour towards fashion and understand and influence fashion consumption trends and patterns (Kontu \& Vecchi, 2014; Ahmad, Salman \& Ashiq, 2015; Chae \& Ko, 2016; Godey, et. al., 2016; Gautam \& Sharma, 2017; Nash, 2019). The communication between fashion brands and consumers has become so engaging and personal that "brands and customers are working together to create new products, services, business models and values" (Kim \& Ko, 2012, 1480). The way social media helps people connect and exchange ideas fundamentally changes the way people engage in fashion consumption (Godey, et. al., 2016; Nash, 2019). Fashion retailers and consumers interact through social media and consumers exchange information about their experience of fashion retailers through social media, actively participating in creating and disseminating the brand's message (Kontu \& Vecchi, 2014). This exchange creates opportunities for fashion retailers to monetise this tool and change the use of social media in the retail fashion industry as social media helps create a feedback loop with fashion retail companies (Kim \& Ko, 2012; Wolney \& Muller, 2013; Henninger, Alevizou \& Oats, 2017; Nash, 2019).

The increased presence of fashion brands and the amount of fashion-related dialogue on social media, as well as the opportunities that these create for fashion retailers has drawn a lot of attention on understanding how social media may impact consumer decision making and consumer behaviour. However, this area of research is still young and mostly topical, and more research is required to get a better understanding of how social media affects consumers (Kontu \& Vecchi, 2014; Gautam \&Sharma, 2017; Chae \& Ko, 2016; Nash, 2019). Interestingly, and perhaps tellingly, there is very little literature on the subject of how social media impacts the behaviour of fashion consumers in Greece and literature on the retail fashion market is noticeably scarce. Studies published on the topic of social media influencing consumer decisions are almost exclusively confined to the tourism sector (Chatzigeorgiou (2017), Kavoura \& Staviraneas (2015), Perakakis, et. al. (2018)). Our research attempts to fill this gap in the literature and to add to the conversation and generate interest for further studies on this topic, perhaps directing towards more comprehensive use of Facebook and Instagram in the marketing sphere.

\section{Data collection}

For our study we selected the geographical location of the island of Rhodes in Greece. The arrival of several chain fashion retailers to the island and the growth of local boutiques in the past few years as well as the confined geography of the island made it an interesting location for our study. We conducted a survey using questionnaires to collect quantitative data to capture how Facebook and Instagram have impacted consumer behaviour in the retail fashion market in Rhodes. Our interest was confided to two social media: Facebook and Instagram. Facebook and Instagram are the two most popular social media in Greece (Hutt, 2017; Vincos, 2019) and although Instagram is lagging behind Facebook in terms of widespread use, the fashion industry has embraced Instagram very quickly and Instagram seems to be the most prominent platform to disseminate fashion news (Cartner-Morley, 2015a \& b).

The survey questionnaire was distributed through social media, using Survey Monkey. Dedicated pages were set up on Facebook and Instagram to invite participants to take part to the research. Potential participants were directed to Survey Monkey, where they could find additional information about the research and the link to the survey. The questionnaire included 18 statements and participants were asked to state their agreement with these using a 5-point Likert scale ranging from $1=$ Strongly agree to $5=$ Strongly disagree. All statements were aimed at capturing how the two social media platforms influence consumer behaviour in the retail fashion marker in Rhodes. Data was collected over the period between mid-November 2017 and $1^{\text {st }}$ January 2018.

For the research, we targeted Rhodian residents who had contact with the fashion retail market, who were permanent or temporary residents of Rhodes at the time of the research (including University students) and who were aged between 18-54. According to a study on The Statistics Portal (2018c), ages from 55-64 have the lowest social media usage. Cox (2010) also argues that usage of social media and positive reactions to social media advertising is considerably lower for users over 55 . For these reasons we have decided not to invite participants over the age of 55 to our study.

\section{Findings}

We collected 115 completed questionnaires. Among the respondents, 55.65\% were between the ages of 25-34, and $20 \%$ of the respondents were between $18-24$. These two age groups have quite high social media presence (The Statistics Portal, 2018c; Kavoura and Stavrianeas, 2015; Hudson \& Hudson, 2013). Also, interestingly, according to Cox (2010), the age group with the highest positive reaction to social media marketing is between 18-28 years old and according to Qualman (2009) young adults actively engage with fashion brands through social media. Also, all our respondents were residing in Rhodes at the time of the research, and more specifically $69.57 \%$ respondents were permanent residents of the island, $26.09 \%$ were temporary residents and the remaining $4.35 \%$ were students. 
The majority of the respondents confirmed that they were regular users of Facebook (84.35\%) or Instagram $(62.83 \%)$. More than half of the participant (54\%) were regular users of both social media platforms, and only a small percentage indicated that they were not regular users of Facebook or Instagram (8.7\% and 22.12\% respectively). As these numbers confirm, Facebook is the predominant social media forum in the area of Rhodes, but Instagram is quite popular as well. These findings are in line with Hutt's (2017) study into the most popular social media networks worldwide, which reflected high usage of both Facebook and Instagram in Greece, with Facebook reigning supreme, and Instagram coming in a close second.

Out of 115 respondents, $75.65 \%$ were in agreement that Facebook and/or Instagram is a good way to follow trends, while only a very small number were in disagreement with this statement $(4.35 \%)$ and $20 \%$ of the respondents were indifferent about this statement. Predominantly the respondents told us that fashion is more accessible today than it was 5 years ago due to Facebook and/or Instagram $(76.75 \%)$ and only a very small percentage (8.7\%) found themselves disagreeing with this statement. More than half of the respondents agreed that they follow fashion brands/stores on Facebook and/or Instagram (55.65\%) and just under half of them (48.7\%) agreed or strongly that they use Facebook and/or Instagram to seek opinions about brands/products. However, only $37.39 \%$ of the respondents indicated that they use Facebook and/or Instagram for fashion inspiration, while an equal percentage were neutral about this statement. It is interesting to comment that although $75.65 \%$ of the respondents thought that Facebook and/or Instagram is a good way to follow trends, only $55.65 \%$ of the respondents told us that they use the two media to follow fashion brands/stores. The percentages dropped even further when it came to seeking opinion over the two media about fashion $(48.7 \%)$ and when it came to seeking fashion inspiration over the two media $(37.39 \%)$. What our findings suggest is that our participants perceived the two social media platforms to be a good way to follow trends, with many of them 'actively' engaging to follow brands/products, a good number of the participants appeared to be less keen.

When we asked our participants about whether Facebook and/or Instagram has influenced where they shop for fashion, we found that the participants were mainly indifferent about presence on the two social media, when selecting the store. More specifically, $40.87 \%$ of the respondents were indifferent to shop from stores that use Facebook and/or Instagram to promote themselves and $41.74 \%$ of the respondents were indifferent about selecting a store because it has a Facebook and/or Instagram presence. Our findings suggest that only about 1/3 of the respondents were swayed by presence on Facebook and/or Instagram when they selected a store and only about 1/4 suggested that they will shop from a store based on its presence on social media, while mainly the respondents were indifferent about a store's presence on social media when making their selection.

When we asked about the impact of Facebook and/or Instagram on how they shop for fashion in general, $34.79 \%$ of the respondents agreed or strongly agreed that they buy fashion they have seen on Facebook and/or Instagram, while $35.66 \%$ of the respondents disagreed or strongly disagreed with this statement and $28.55 \%$ were neutral. Also, $38.26 \%$ of the respondents agreed or strongly agreed that they are more likely to buy fashion after they have seen a product on Facebook and/or Instagram, while 33.05\% disagreed or strongly disagreed with this statement and $28.24 \%$ were neutral. What these findings suggest is that there was no "majority vote" as such about either of these two statements. And while there was a significant percentage of participants who indicated that that they frequently buy fashion that they have seen on the two social media and who are more likely to buy fashion after they have seen the product on the two social media, there was about $1 / 3$ of the respondents who disagreed with both statements.

Asking specifically about local stores and shopping for fashion locally, the majority of the respondents (48.7\%) agreed that they use Facebook and/or Instagram to find out about local fashion stores and products, while the remaining of the participants were almost equally split between being neutral (26.09\%) or disagreeing/strongly disagreeing (25.22\%) with this statement. Also, $46.09 \%$ of the respondents agreed that Facebook and/or Instagram promotion has changed the way they shop for local fashion, while the number of participants that disagreed or strongly disagreed with this statement was $29.57 \%$. However, when we asked participants to indicate whether they subscribe to Facebook and/or Instagram updates and alerts regarding brands or products in the Rhodes area, $47.83 \%$ disagreed or strongly with this statement, while only $30.04 \%$ respondents agreed. Again, we notice that when it comes to active engagement with the two social media in the form of subscribing to updates and alerts, our participants were less keen to keep up. While our participants suggested that they seek information about local fashion and this seems to have changed the way they shop for fashion locally, they were not invested enough to have alerts or subscriptions set-up. What this means is that while the Rhodes weren't subscribers per se, they did use these social media to follow what is happening in the local retail marketplace. Respondents suggested that they will use social media to stay abreast with local fashion and retail developments, however they lack the interest to subscribe to alerts or notifications from these outlets.

In relation to their buying behaviour, $38.26 \%$ of the respondents disagreed or strongly disagreed that their buying behaviour for fashion had changed because of Facebook and/or Instagram, 34.79\% agreed with that statement, while $26.96 \%$ were neutral. Also, $43.48 \%$ of the respondents disagreed that they made unplanned purchases due to exposure to Facebook and/or Instagram, 33.05\% agreed or strongly with this statement and $23.48 \%$ of the participants were neutral.

Finally, we asked the participants to compare the impact of Facebook and/or Instagram on their purchasing behaviour with that of traditional media. Just over half of the respondents (50.44\%) agreed or strongly that Facebook and/or Instagram were more influential in their purchasing decision than traditional media and only $22.61 \%$ disagreed or strongly disagreed with this statement. However, when the participants were asked to consider whether they find fashion advertising on Facebook and/or Instagram more interesting than traditional media, the percentage 
of those who agreed or strongly was slightly lower and dropped to $42.60 \%$, while $39.13 \%$ of the participants were neutral toward this statement.

\section{Discussion and Conclusions}

This study was conducted to investigate how Facebook and/or Instagram affect the shopping behaviour of fashion consumers on the Greek island of Rhodes. We aimed to explore how the two social media are impacting the way Rhodians shop for fashion and the extent to which the two social media serve as a source of fashion information and inspiration for the Rhodians. We found that, although not to the extent that we expected, Facebook and Instagram are indeed impacting the way Rhodians shop for fashion. Facebook and/or Instagram are impacting where Rhodians shop for fashion and the Rhodians look on Facebook and/or Instagram and refer to these social media to help them form decisions about buying fashion. The two social media are a source of fashion information and inspiration for the Rhodians, although perhaps not so much through active engagement but more through passive exposure to information.

Although the impact of the two social media on the Rhodians' buying behaviour is not as strong as we expected, to put the findings in context, it should be considered that Greece continues to be a county in recession and that the apparel and clothing sector is only just picking up slowly (The Statistics Portal, 2018a) and that internet usage in the country is increasing (Hellenic Statistical Authority, 2018) but the country continues to have one of the lowest rates of regular use of the internet by individuals among EU countries (European Commission, 2019).

The Rhodians think that Facebook and/or Instagram is a good way to follow trends which is in line with earlier findings according to which consumers increasingly rely on the two social media to follow trends (Mohr, 2013; Ko, et. al., 2013; Wonly \& Mueller, 2013). Also, as anticipated (Morh, 2013; Ahmad, Salman \& Ashiq, 2015; Cartner-Morley, 2105a), the Rhodians think that the two social media are making fashion more accessible today than it was 5 years ago. This is an interesting finding about the strength of these two social media platforms in bringing fashion closer to consumers and the potential that the two media could have as marketing tools (Kontu \& Vecchi, 2014; Gautam \& Sharma, 2017; Felix, Rauschnable \& Hinsch, 2017).

The Rhodian consumers may follow brands on Facebook and/or Instagram and they may seek opinions on these social media about brands/products, but they do not feel strongly about Facebook and/or Instagram as the source where they will seek fashion inspiration. Throughout the research, we assumed that the Rhodians would turn to social media for fashion inspiration. This implied that people would actively use Facebook and/or Instagram to search for fashion news, fashion images, opinions and recommendations about fashion, as sources of fashion inspiration. What we found was that the Rhodians aren't subscribers per se, but they do use these social media to follow what is happening in the fashion retail marketplace. Respondents told us that they will use social media to stay abreast with fashion and retail developments, however many of them will not subscribe to alerts or notifications about fashion. This may have very useful implications for the development of fashion content that engages potential consumers in social media. As Ko et. al. (2013) suggest, in order to engage consumers in discussions about fashion in social media platforms, the content needs to be engaging and relevant to them and frameworks for content development need to be created in order to achieve this goal.

There seem to be mixed findings in the literature about the effectiveness of social media compared to traditional media in the marketing mix and this is supported by our findings as well. Compared to traditional media, our findings do not suggest any strong dominance of these two social media over traditional media in terms of the interest of the content and the influence on the purchase decision. Social media adds a social element to the promotion of fashion, with consumers engaging with the fashion brands and with other fashion consumers and this creates new opportunities for fashion retailers (Kim \& Ko, 2012; Gautman \& Sharma, 2017), but as Ahmad, Sahman \& Ashing (2015) and Godey et. al. (2016) suggest both social and traditional media have a role to play in the promotion of fashion brands.

As social media has changed the way fashion retailers connect with consumers, a number of different opportunities have emerged, from fashion blogs, to broadcasting fashion shows and sharing fashion videos and pictures on social media, to internet communities, celebrity recommendations and customer reviews and ratings (Kim \& Ko, 2012; Godey et. al., 2016; Ahmed, Salman \& Ashiq, 2015, Gautam \& Sharma, 2017; Nash, 2019). In light of our findings that the Rhodians do take an interest in Facebook and/or Instagram when engaging with the fashion industry and that the two social media do impact the Rhodian consumers' shopping behaviour, it would be interesting to engage in a more in-depth investigation of what content is more impactful in shaping shopping behaviour. Also, it would be interesting to investigate in-depth the impact of the different social commerce constructs such as product/service recommendations and referrals, reviews and ratings or forums and communities on the behaviour of retail fashion consumers.

\section{References}

Ahmad N., Salman A. and Rubab A. 2015. "The impact of Social Media on Fashion Industry: Empirical Investigation from Karachiites". Journal of Resources Development and Management, 7, 1-7.

Bruhn, M., Schoenmueller, V. and Schafer, D.B. 2012. "Are social media replacing traditional media in terms of brand equity creation?”. Management Research Review, 35(9), 770-790.

DOI: $10.25103 /$ ijbesar.122.07 
Cartner-Morley, J. 2015a "Instagram: Welcome to fashion's new front row". The Guardian. [Online]. Available from: https://www.theguardian.com/fashion/2015/sep/25/instagram-the-new-catwalk-of-fashion [Accessed: 08 June 2019].

Cartner-Morley, J. 2015b "How socality barbie proves that Instagram has turned into reality TV". The Guardian. [Online]. Available from: https://www.theguardian.com/fashion/2015/sep/14/how-socality-barbie-proves-that-instagram-has-turnedinto-reality-tv [Accessed: 08 June 2019].

Chae, H. and Ko, E. 2016. "Customer social participation in the social networking services and its impact upon the customer equity of global fashion brands". Journal of Business Research, 69(9), 3804-3812.

Chatzigeorgiou, C. 2017. "Modelling the impact of social media influencers on behavioural intentions of millennials: The case of tourism in rural areas in Greece". Journal of Tourism, Heritage E Services Marketing, 3(2), 25-29.

Chen, A., Lu, Y. and Wang, B. 2017. "Customers' purchase decision-making process in social commerce: A social learning perspective”. International Journal of Information Management, 37, 627-638.

Consenza, V. 2018. "World map of social networks". [Online]. Available from: http://vincos.it/world-map-of-social-networks/ [Accessed: 03 December 2018].

Cox S.A. 2010. "Online Social Network Member Attitude Toward Online Advertising Formats". MA thesis, The Rochester Institute of Technology.

ELTRUN 2016. "Internet users in Greece say they are more mature and conscious relative to the use of social media and the tools of social media marketing on behalf of companies". [Online]. Available from: http://www.greekecommerce.gr/gr/filedownload/eltrun-digital-marketing-2016 [Accessed: 02 June 2019].

Erkan, I. and Evans, C. 2016. "The influence of eWOM in social media on consumers' purchase intentions: An extended approach to information adoption". Computers in Human Behavior, 61, 47-55.

Euromonitor International. 2019. "Apparel and footwear in Greece". [Online]. Available from: https://www.euromonitor.com/apparel-and-footwear-in-greece/report [Accessed: o9 June 2019].

European Commission. 2019. "Use of Internet services". [Online]. Available from: https://ec.europa.eu/digital-singlemarket/en/use-internet [Accessed: 16 June 2019].

Gautam, V. and Sharma, V. 2017. "The mediating role of customer relationship on the social media marketing and purchase intention relationship with special reference to luxury fashion brands". Journal of Promotion Management, o(0), 1-17.

Geissinger A. and Laurel C. 2016. "User engagement in social media - an explorative study of Swedish fashion brands". Journal of Fashion Marketing and Management, 20,(2) 177-190.

Godey, B. Manthiou, A., Pederzoli, D., Rokka, J., Aiello, G., Donvito, R. and Singh, R. 2016. "Social media marketing efforts of luxury brands: Influence on brand equity and consumer behaviour". Journal of Business Research, 69, 5833-5841.

Goh, K.-Y., Heng, C.-S. and Lin, Z. 2013. "Social media brand community and consumer behavior: Quantifying the relative impact of user- and marketeer-generated content”. Information Systems Research, 24(1), 88-107.

Goodrich, K. and de Mooij, M. 2013. "How 'social' are social media? A cross-cultural comparison of online and offline purchase decision influences". Journal of Marketing Communications, 20(1-2), 103-114.

Hajli, M.N. 2014. "A study of the impact of social media on consumers". International Journal of Market Research, 56(3), 387-404.

Hatzithomas L., Fotiadis T.A. and Courdounaris D.N. 2016. "Standardization, Adaptation, and Personalization of International Corporate Social Media Communications". Psychology and Marketing, 33(12), 1098-1 105.

Hellenic Statistical Authority. 2018. "Press Release - Survey on the use of Information and Communication Technologies by households and individuals: 2018”. [Online]. Available from: https://www.statistics.gr/en/statistics/-/publication/SFA20/[Accessed: O2 June 2019].

Henninger C.E., Alevizou P.J. and Oates C.J. 2017. "IMC, social media and UK fashion micro-organisations". European Journal of Marketing, 51(3), 668-691.

Hudson, S. and Hudson, R. 2013. "Engaging with consumers using social media: a case study of music festivals". International Journal of Event and Festival Management, 4(3), 206-223.

Hutt R. 2017. "The World's Most Popular Social Networks Mapped. World Economic Forum. [Online]. Available from: https://www.weforum.org/agenda/2017/03/most-popular-social-networks-mapped/, [Accessed: 01 September 2017].

Kavoura A. and Stavrianeas A. 2015. "The importance of social media on holiday visitors" choices - the case of Athens". Greece, EuroMed Journal of Business, 10(03), 360-374.

Kim, A.J. and Ko, E. 2012. "Do social media marketing activities enhance customer equity? An empirical study of luxury fashion brand". Journal of Business Research, 65, 1480-1486.

Kim, S. and Park, H. 2013. "Effects of various characteristics of social commerce (S-commerce) on consumers' trust and trust performance". International Journal of Information Management, 33, 31 8-332.

Ko, E., Chun, E., Song, S. and Kim, K.H. 2013. "Which content types increase participation in fashion social platforms?". Journal of Global Scholars of Marketing Science, 23(3), 297-313.

Kontu, H. and Vecchi, A. 2014. "Why all that noise - assessing the strategic value of social media for fashion brands". Journal of Global Fashion Marketing, 5(3), 235-250.

Kourtali, E. 2018. "Foreign investors concerned about growth rate, Greek stocks". Ekathimetini. [Online]. Available from: http://www.ekathimerini.com/232923/article/ekathimerini/business/foreign-investors-concerned-about-growth-rate-greekstocks [Accessed: 03 December 2018].

Lim, K.H., Sia, C.L., Lee, M.K.O. and Benbasat, I. 2006. "Do I trust you online, and if so will I buyt? An empirical study of two trust building strategies". Journal of Management Information Systems, 23(2), 233-266.

Lin, X., Li, Y. and Wang, X. 2017. "Social commerce research: Definition, research themes and trends". International Journal of Information Management, 37, 190-201.

Mohr, I. 2013. "The impact of social media on the fashion industry". Journal of Applied Business and Economics, 15(2), 17-22.

Nash, J. 2019. "Exploring how social media platforms influence fashion consumer decisions in the UK retail sector". Journal of Fashion Marketing and Management, 23(1), 82-103.

Ng, M. 2014. "Social media and luxury fashion brands in China: The case of Coach". Journal of Global Fashion Marketing, 5(3), 251265.

Paquette H. 2013. "Social Media as a Marketing Tool: A Literature Review”. Major Papers by Master of Science Students. Paper 2 [Online] Available from: http://digitalcommons.uri.edu/tmd_major_papers/2. [Accessed: 14 August 17]. 
Park, J., Ciampaglia, G.L. and Ferrara, E. 2016. "Style in the age of Instagram Predicting success within the fashin industry using social media". Proceedings of the $19^{\text {th }}$ ACM Conference on computer-supported cooperative work \& social computing, 64-73, San Francisco, California, February 27 - March 22016.

Patino, A., Pitta, D. and Quinones, R. 2012. "Social media's emerging importance in market research". Journal of Consumer Marketing, 29(3), 233-237.

Perakakis, E., Trihas, N., Venitourakis, M., Mastorakis, G. and Kopanakis, I. 2018. "Social media as a marketing tool for Greek destinations". Tourismos: An International Multidisciplinary Journal of Tourism, 11(3), 157-181.

Perry, P. and Kyriakaki, M. 2014. "The decision-making process of luxury fashion retail buyers in Greece". Journal of Fashion Marketing and Management, 18(1), 85-106.

Rathore, A.K., Ilavarasan, P.V. and Dwivedi, Y. 2016. "Social media content and product co-creation: An emerging paradigm". Journal of Enterprise Information Management, 29(1), 7-18.

Schivinski, B. and Dabrowski, D. 2016. "The effect of social media communication on consumer perceptions of brands". Journal of Marketing Communications, 22(2), 189-214.

Shadkam, M. and O'Hara, J. 2013. "Social commerce dimensions: The potential leverage for marketers". Journal of International Banking and Commerce, 18(1), 1-14.

Shankar V., Inman J., Mantrala M., Kelley E. and Rizley R. 2011. "Innovations in Shopper Marketing: Current Insights and Future Research Issues.” Journal of Retailing, 1:s29-s42, doi:10.1016/j.jretai.2011.04.007.

Shankar V., Inman J.J., Mantrala M., Kelly E. and Rizley R. 2011. "Innovations in Shopper Marketing: Current Insights and Future Research Issues". Journal of Retailing 87S, 1-2011, 29-42.

The Statistics Portal. 2018a. "Apparel". [Online]. Available from: https://www.statista.com/outlook/90000000/138/apparel/greece [Accessed: 09 June 2019].

The Statistics Portal. 2018b. "Number of retail chains in Greece in 2018, by sector". [Online]. Available from: https://www.statista.com/statistics/642362/retail-chains-number-by-sector-greece/ [Accessed: 09 June 2019].

The Statistics Portal. 2018c. "Age distribution of active social media users worldwide as of 3rd quarter 2014, by platform". [Online] Available from: https://www.statista.com/statistics/274829/age-distribution-of-active-social-media-usersworldwide-by-platform/. [Accessed: 10 September 2017].

The Statistics Portal. 2019. "Share of households with internet access in Greece from 2007 to 2018 ". [Online $]$. Available from: https://www.statista.com/statistics/377701/household-internet-access-in-greece/ [Accessed: 02 June 2019].

Qualman,E. 2009 "Socialnomics, How Social media transforms the way we live and do the business". John Wiley \& Sons, Inc.

Vincos. 2019. "World map of social media networks". [Online]. Available from: https://vincos.it/world-map-of-social-networks/ [Accessed: 02 June 2019].

Wolny J. and Mueller C. 2015. "Analysis of fashion consumers' motives to engage in electronic word-of-mouth communication through social media platforms”. Journal of Marketing Management, 29( 5-6), 562-583. 